\title{
EFEKTIVITAS PENERAPAN MODEL QUANTUM LEARNING DENGAN PENDEKATAN REALISTIC MATHEMATICS EDUCATION (RME) TERHADAP HASIL BELAJAR SISWA
}

\section{THE EFFECTIVENESS OF APPLYING QUANTUM LEARNING MODEL WITH REALISTIC MATHEMATICS EDUCATION (RME) APPROACH TOWARDS THE STUDENTS LEARNING OUTCOMES}

\author{
Fausiah Syafruddin ${ }^{1)}$, Jeranah ${ }^{2)}$ \\ 1,2)Program Studi Pendidikan Matematika STKIP YPUP Makassar \\ fausiah38@gmail.com ${ }^{1}$, jeranahku@gmail.com ${ }^{2)}$
}

\begin{abstract}
Abstrak
Penelitian ini bertujuan untuk mendeskripsikan keefektifan model Quantum Learning dengan pendekatan Realistic Mathematics Education (RME) terhadap hasil belajar siswa. Jenis penelitian ini adalah penelitian eksperimen dengan pre-experimental design. Populasi dalam penelitian adalah seluruh siswa kelas VII SMPN 1 Maros tahun ajaran 2018/2019 dengan jumlah 267 siswa, sedangkan sampel dalam penelitian ini adalah 29 siswa dari kelas VII-1 yang dipilih dengan teknik cluster random sampling. Instrumen penelitian yang digunakan adalah tes hasil belajar pretest dan posttest, lembar observasi, dan angket respons siswa. Data yang terkumpul dianalisis dengan menggunakan teknik analisis statistika deskriptif dan inferensial. Dari hasil analisis yang diperoleh: (1) hasil belajar matematika siswa mencapai KKM, (2) peningkatan hasil belajar siswa setelah penerapan model Quantum Learning dengan pendekatan RME terbanyak berada pada kategori baik yaitu 48,3\%, (3) aktivitas siswa berada pada kategori baik dengan rata-rata persentase yaitu 83,996\%, (4) keterlaksanaan pembelajaran siswa berada pada kategori sangat baik dengan rata-rata persentase yaitu 87,17\%, (5) respons siswa berada pada kategori positif dengan rata-rata sebesar 89,65\%. Berdasarkan hasil penelitian, dapat disimpulkan bahwa model quantum learning dengan pendekatan RME efektif untuk meningkatkan hasil belajar matematika siswa.
\end{abstract}

Kata Kunci: hasil belajar, quantum learning, realistic mathematics education

\begin{abstract}
This study aims to describe the effectiveness of the Quantum Learning model with Realistic Mathematics Education (RME) approach towards the students learning outcomes. This type of research is experimental research with pre-experimental design. The population in the study were all students of class VII SMPN 1 Maros in the 2018/2019 academic year with 267 students, while the sample in this study was 29 students from class VII-1 who were selected by cluster random sampling technique. The research instrument used was the pretest and posttest learning outcomes test, observation sheets, and students response questionnaire. The collected data were analyzed using descriptive and inferential statistical analysis techniques. From the results of the analysis obtained: (1) students mathematics learning outcomes reach the KKM, (2) the increase in students learning outcomes after the application of the Quantum Learning model with the RME approach is mostly in the good category, namely 48.3\%, (3) students activity is in good category with an average percentage of $83.996 \%$, (4) the students learning implementation is in very good category with an average percentage of $87.17 \%$, (5) students responses are in the positive category with an average of $89.65 \%$. Based on the research results, it can be concluded that quantum learning model with RME approach is effective for improving students' mathematics learning outcomes.
\end{abstract}


Keywords: learning outcomes, quantum learning, realistic mathematics education

How to Cite: Syafruddin, S. \& Jeranah. (2020). Efektivitas penerapan model quantum learning dengan pendekatan realistic mathematics education terhadap hasil belajar siswa. Al asma: Journal of Islamic Education, 2(2), 224-235.

\section{PENDAHULUAN}

Dari tahun ke tahun populasi manusia di Indonesia semakin banyak, padahal pemerintah sudah menyarankan program KB (Keluarga Berencana) tetapi tetap saja populasi semakin bertambah. Masalah ini memberi dampak besar terhadap berbagai macam lingkup kehidupan, salah satunya di lingkungan sekolah. Banyaknya siswa yang bertambah setiap tahun mengakibatkan setiap siswa dalam satu kelas semakin banyak sehingga siswa saling menganggu pada saat proses belajar mengajar berlangsung. Efektifnya banyaknya siswa dalam satu kelas ketika proses belajar mengajar adalah 25 orang. Pada kenyataanya sekarang jumlah siswa di setiap kelas melebihi kapasitas efektif. Banyaknya siswa di kelas dapat mempengaruhi proses belajar mengajar. Kelas menjadi tidak terkontrol sehingga penyampaian materi tidak berjalan dengan baik ketika guru menjelaskan. Masalah ini dapat mempengaruhi hasil pembelajaran siswa, apabila guru tidak dapat menanganinya dengan baik, khususnya pada mata pelajaran yang membutuhkan pemahaman yang baik ketika belajar, salah satunya pada mata pelajaran matematika.

Mata pelajaran matematika merupakan salah satu mata pelajaran wajib yang harus diajarkan mulai dari jenjang SD/MI, SMP/MTs, dan SMA/MA (Inganah, Cholily, Taufik, \& Ummah, 2018: 152). Pada pembelajaran matematika diperlukan motivasi dan pemikiran yang fokus dalam memahami suatu materi yang diberikan sebab matematika merupakan ilmu yang membutuhkan pemahaman dan bukan hafalan (Afriyanti, Wardono, \& Kartono, 2018: 609). Para siswa seringkali beranggapan bahwa mata pelajaran matematika merupakan pelajaran yang sulit dikarenakan proses pembelajaran yang abstrak sehingga menumbuhkan pemikiran bahwa siswa merasa tidak mampu dalam mempelajari matematika. Hal ini menyebabkan minat untuk belajar matematika di luar sekolah menjadi kurang peminat (Sartika \& S, 2019: 150).

Salah satu hambatan yang didapatkan guru dalam pembelajaran matematika adalah pengaplikasian materi pada proses belajar mengajar. Banyak siswa yang belum termotivasi untuk belajar matematika karena mereka menganggap matematika adalah pelajaran yang sangat membosankan dan banyak dari siswa masih belum mengerti arti dan pengaplikasian dari pembelajaran matematika dalam kehidupan sehari-hari. Hal ini disebabkan karena siswa hanya mendapatkan materi terus-menerus pada proses belajar mengajar tanpa adanya umpan balik dari guru berupa contoh materi pembelajaran yang dikaitkan dengan lingkungan hidup sekitar, sedangkan matematika merupakan ilmu yang mempunyai peranan sangat penting dalam berbagai aktivitas yang dilakukan manusia dalam kehidupan sehari-hari. Aktivitas manusia dalam kehidupan sehari-hari tidak lepas dari pemanfaatan dan penerapan konsep-konsep yang ada dalam matematika. Pemahaman yang baik terhadap konsep matematika akan membantu dalam memecahkan beberapa persoalan yang terdapat dalam kehidupan sehari-hari (Prasetyo, 2020: 111). 
Berdasarkan hasil observasi dan wawancara terhadap salah satu guru matematika di SMPN 1 Maros pada hari Kamis 29 Maret 2018 pukul 10.15 wita mengemukakan bahwa ada dua masalah yang menghambat proses belajar mengajar di kelas. Pertama, kebanyakan dari siswa kurang termotivasi dalam proses pembelajaran matematika karena siswa menganggap matematika sangat rumit dipelajari. Kurangnya motivasi dalam belajar matematika yang dialami siswa dapat mempengaruhi hasil belajar. Hal ini sejalan dengan penelitian Sekar Anggayuh \& Achmad Rifai (2019: 121-130) dan Silfitrah \& Wahyuni (2020: 53-60) yang menyatakan bahwa terdapat pengaruh yang signifikan minat dan motivasi belajar terhadap hasil belajar siswa. Kedua, siswa selalu mengeluh untuk apa mempelajari matematika dan jarang mendapatkan contoh aplikasi materi dalam proses belajar mengajar di kelas padahal banyak manfaat dari pembelajaran matematika yang dapat diterapkan dalam kehidupan sehari-hari. Oleh karena itu, penulis memberi saran dalam proses belajar matematika dibuat menyenangkan dan tidak dibuat abstrak tapi menjadi real dan melibatkan kehidupan nyata. Sehingga guru harus mampu menerapkan suatu model pembelajaran yang efektif untuk mengembangkan motivasi dan minat siswa dalam pembelajaran matematika melalui pendekatan pengaplikasian kehidupan sehari-hari.

Dari dua masalah tersebut dan berdasarkan diskusi dengan pihak guru matematika di sekolah tersebut terkait kondisi siswa, penulis berpikir untuk mengatasi dengan menerapkan model quantum learning yang merupakan model pembelajaran yang membiasakan belajar menyenangkan. Quantum learning adalah seperangkat model dan falsafah belajar yang terbukti efektif di sekolah dan bisnis untuk semua tipe orang dan segala usia. Quantum learning pertama kali digunakan di Supercamp, DePotter (Huda, 2015: 192-193). Supercamp merupakan suatu program yang mengembangkan rasa percaya diri, keterampilan belajar, dan keterampilan berkomunikasi pada lingkungan yang menyenangkan (Riati \& Farida, 2017: 16). Model quantum learning akan memberikan kebebasan kepada siswa untuk menemukan pengalaman-pengalaman baru dalam belajar sehingga suasana proses pembelajaran lebih nyaman dan menyenangkan (Hayati \& Husnidar, 2018: 18). Quantum learning menyajikan materi melalui 6 langkah yang dikenal dengan TANDUR. TANDUR merupakan singkatan dari Tumbuhkan Minat, Alami, Namai, Demonstrasikan, Ulangi, dan Rayakan (Sudarman \& Vahlia, 2016: 276). Hasil akhir dari model quantum learning adalah siswa mampu menyimpulkan isi pembelajaran dengan langkah TANDUR (Swandewi, Gita, \& Suarsana, 2019: 34). Penerapan model ini diharapkan dapat meningkatkan minat belajar siswa melalui pembelajaran yang menyenangkan sehingga pada akhirnya siswa dapat meningkatkan hasil belajar secara menyeluruh.

Menurut Fathurrohman, (2015: 189), penerapan model quantum learning dapat dilakukan dengan pendekatan Realistic Mathematics Education (RME). RME merupakan suatu pendekatan pembelajaran matematika yang menggunakan situasi dunia nyata atau suatu konteks yang real dan pengalaman siswa sebagai titik tolak belajar matematika. Melalui pendekatan ini siswa diajak untuk membentuk pengetahuannya sendiri berdasarkan pengalaman yang telah mereka dapatkan atau alami sebelumnya (Fathurrohman, 2015: 189). Tidak seperti pembelajaran secara umum, dimana pembelajaran matematika berpusat pada pemberian informasi kemudian menggunakannya untuk memecahkan suatu masalah. Akan tetapi melalui pendekatan RME memungkinkan pembelajaran matematika berorientasi pada siswa untuk menemukan dan mengkonstruksikan kembali konsep matematika dan menyelesaikan masalah dalam 
kehidupan sehari-hari (Khotimah \& As'ad, 2020: 492). Melalui pendekatan ini guru dapat menciptakan pembelajaran yang dekat dengan kehidupan sehari-hari.

Berdasarkan uraian di atas, penulis melakukan penelitian dengan judul "Efektivitas Penerapan Model Quantum Learning dengan Pendekatan Realistic Mathematics Education (RME) terhadap Hasil Belajar Siswa Kelas VII.1 SMPN 1 MAROS" untuk melihat keefektifan model pembelajaran Quantum Learning dengan pendekatan Realistic Mathematics Education.

\section{METODE PENELITIAN}

Jenis penelitian ini adalah penelitian pre-eksperimental design, dikarenakan masih terdapat variabel luar yang ikut berpengaruh terhadap terbentuknya variabel dependent. Pre-eksperimental design tidak memasukkan kelompok kontrol atau masih ada variabel luar yang ikut berpengaruh terhadap variabel dependent (Jakni, 2016: 69). Desain penelitian yang digunakan adalah desain pretest-posttest satu kelompok. Pada desain terdapat pretest sebelum diberi perlakuan dan posttest setelah diberi perlakuan, dengan ini kita dapat membandingkan hasil belajar sebelum dan setelah perlakuan (Sudjana \& Ibrahim, 2010: $35)$.

Tabel 1. Desain Pretest-Posttest Satu Kelompok

\begin{tabular}{ccc}
\hline Pretest & Variabel bebas & Posttest \\
\hline$Y_{1}$ & $\mathrm{X}$ & $Y_{2}$ \\
\hline
\end{tabular}

Keterangan :

$Y_{1} \quad$ : Memberikan pretest untuk mengukur variabel terikat sebelum perlakuan.

$\mathrm{X} \quad$ : Memberikan perlakuan eksperimen kepada para subjek.

$Y_{2} \quad$ : Memberikan tes lagi untuk mengukur variabel terikat setelah perlakuan.

Penelitian ini dilaksanakan pada semester ganjil tahun ajaran 2018/2019 di kelas VII $_{1}$ SMPN 1 Maros, JL. Bahagia No.1 Maros, Kel. Alliritengae, Kec. Turikale, Kab. Maros, Sulawesi Selatan. Populasi dan sampel dari penelitian ini adalah siswa kelas VII ${ }_{1}$ SMPN 1 Maros, yang berjumlah 29 orang dengan siswa 16 orang dan siswi 13 orang pada tahun pelajaran 2018/2019. Dalam penelitian menggunakan teknik penarikan sampel random sederhana. Adapun desain perlakuan dalam penelitian ini dengan menggunakan model quantum learning dengan pendekatan RME adalah sebagai berikut:

Langkah 1 : Peneliti menjelaskan tujuan pembelajaran atau kompetensi dasar yang ingin dicapai.

Langkah 2 : Peneliti memberikan motivasi siswa untuk belajar lebih giat dan memperhatikan guru pada saat proses belajar mengajar berlangsung.

Langkah 3 : Peneliti menata lingkungan belajar yang kondusif serta memupuk sikap juara kepada setiap siswa dan memberikan contoh kontekstual dalam kehidupan sehari-hari mengenai materi penyajian data yang akan diajarkan.

Langkah 4 : Peneliti memaparkan materi penyajian data dan memberikan soal kepada siswa agar dapat memahamai contoh kontekstual yang diberikan.

Langkah 5 : Peneliti membebaskan cara belajar siswa agar siswa lebih nyaman dalam berdiskusi hasil kerja soal-soal yang diberikan.

Langkah 6 : Peneliti menarik kesimpulan dari hasil diskusi. 
Teknik pengumpulan data yang digunakan adalah tes hasil belajar yaitu tes hasil belajar sebelum perlakuan (pretest) dan tes hasil belajar setelah perlakuan (posttest), angket, dan observasi. Teknik analisis data yang digunakan yaitu analisis deskriptif dan analisis inferensial. Analisis deskriptif terdiri dari mean, median, modus, variansi, dan standar deviasi. Analisis inferensial terdiri dari uji normalitas untuk mengetahui bahwa data sampel berasal dari populasi yang berdistribusi normal (Gunawan, 2013: 71) dan uji hipotesis untuk menjawab kebenaran dari suatu hipotesis. Uji hipotesis menggunakan uji t dua rata-rata dengan membandingkan hasil belajar siswa sebelum perlakuan dan setelah perlakuan (Tiro, 2015: 263).

Menurut Jeranah (2017: 138) dalam penelitian ini terdapat indikator yang penting sehingga penelitian dapat dikatakan efektif yaitu : (1) Hasil belajar siswa memenuhi kriteria ketuntasan minimal (KKM) yang ditentukan oleh sekolah yang bersangkutan yakni 80\% siswa mencapai nilai minimal sama dengan 75 , baik secara deskriptif maupun inferensial; (2) Rata-rata peningkatan hasil belajar siswa setelah pembelajaran matematika dengan penerapan model quantum learning dengan pendekatan RME mencapai skor 0,3 atau kategori sedang, baik secara deskriptif dan inferensial; (3) Aktivitas siswa. Kriteria keberhasilan aktivitas siswa ditunjukkan dengan minimal 80\% siswa terlihat aktif selama proses pembelajaran berlangsung; (4) Keterlaksanaan pembelajaran. Dalam penelitian ini, keberhasilan keterlaksanaan pembelajaran apabila minimal 85\% aktivitas guru telah terlaksana saat proses pembelajaran berlangsung; (5) Respons siswa. Kriteria yang ditetapkan dalam penelitian ini adalah minimal $80 \%$ siswa yang memberikan respons positif terhadap semua aspek yang ditanya.

Adapun hipotesis statistik dalam penelitian ini adalah sebagai berikut:

1. $\mathrm{H}_{0}: \mu_{2} \leq 75$

$\mathrm{H}_{1}: \mu_{2}>75$

2. $\mathrm{H}_{0}$ : Gain $\leq 0,30$

$\mathrm{H}_{1}$ : Gain $>0,30$

Keterangan :

$\mu_{2} \quad$ : Rata-rata hasil belajar matematika setelah penerapan model quantum learning dengan pendekan RME.

Gain : Rata-rata peningkatan hasil belajar siswa setelah penerapan model quantum learning dengan pendekatan RME.

\section{HASIL DAN PEMBAHASAN}

Setelah dilaksanakannya penelitian oleh peneliti diperoleh data-data kuantitatif dan kualitatif. Data-data tersebut telah peneliti olah baik secara manual maupun SPSS sehingga diperoleh data sebagai berikut:

\section{Hasil Analisis Deskriptif}

Hasil analisis statistik deskriptif digunakan untuk mendeskripsikan hasil belajar matematika yang diperoleh oleh siswa. Untuk mendapatkan gambaran yang jelas tentang hasil belajar matematika siswa maka dilakukan tes sebelum pembelajaran dan setelah pembelajaran dengan menggunakan model quantum learning dengan pendekatan RME. 


\section{a. Deskripsi Hasil belajar Matematika Siswa sebelum Penerapkan Model Quantum Learning dengan Pendekatan RME.}

Berdasarkan hasil penelitian yang telah dilakukan di SMPN 1 Maros, hasil analisis statistik yang berkaitan dengan skor hasil belajar matematika siswa sebelum diajar dengan model quantum learning dengan pendekatan RME disajikan dalam tabel 2.

Tabel 2. Deskripsi Skor Hasil Belajar Matematika Siswa Kelas VII 1 SMPN 1 Maros sebelum Penerapkan Model Quantum Learning dengan Pendekatan RME

\begin{tabular}{cc}
\hline Statistik & Nilai Statistik \\
\hline Ukuran sampel & 29 \\
Skor terendah & 5 \\
Skor tertinggi & 55 \\
Rata-rata & 25,69 \\
Skor ideal & 100 \\
Varians & 190,57 \\
Standar deviasi & 13,805 \\
Median & 25 \\
Modus & 25 \\
Jangkauan & 50 \\
\hline
\end{tabular}

Berdasarkan tabel 2, nilai dari 29 siswa yang diajar dengan menggunakan model quantum learning dengan pendekatan RME diperoleh nilai terendah 5 dan nilai tertinggi 55 dengan rentang nilai 50. Nilai yang mewakili sekumpulan nilai hasil belajar siswa yang menggunakan model quantum learning dengan pendekatan RME adalah 25,69 dengan standar deviasi adalah 13,805 artinya penyebaran datanya dominan berada pada 11,885 sampai 39,495 yang berkisaran antara 12 sampai 40 dari skor ideal 100. variansi 190,57 yang artinya tingkat kemampuan siswa cukup bervariasi (Nurhusain, 2016:19). Median 25 yang berarti $50 \%$ dari jumlah siswa memperoleh nilai di atas 25 dan 50\% siswa memperoleh nilai dibawah 25. Modus 25 yang berarti nilai terbanyak yang diperoleh siswa adalah 25.

Dari keseluruhan nilai pretest, jika dikelompokkan ke dalam empat kategori hasil belajar, maka distribusi frekuensi, persentase, dan kategori hasil belajar seperti yang ditunjukkan pada tabel 3.

Tabel 3. Distribusi Frekuensi dan Persentase Tes Hasil Belajar Siswa sebelum Penerapkan Model Quantum Learning dengan Pendekatan RME

\begin{tabular}{ccccc}
\hline No. & Interval & Frekuensi & Persentase (\%) & Kategori \\
\hline 1 & $91-100$ & 0 & 0 & Baik Sekali \\
2 & $83-91$ & 0 & 0 & Baik \\
3 & $75-83$ & 0 & 0 & Cukup \\
4 & $<75$ & 29 & 100 & Kurang \\
\hline & Jumlah & $\mathbf{2 9}$ & $\mathbf{1 0 0}$ & \\
\hline
\end{tabular}

Dari tabel 3 dapat diketahui bahwa dari 29 orang siswa kelas VII 1 SMPN 1 Maros, sebelum penerapan model quantum learning dengan pendekatan RME dengan semua skor hasil belajar $<75$ dan skor rata-rata 25,69 sehingga dapat disimpulkan bahwa rata-rata hasil belajar matematika siswa sebelum penerapan model quantum learning dengan pendekatan RME berada pada kategori kurang. 


\section{b. Deskripsi Hasil Belajar Siswa setelah Penerapkan Model Quantum Learning dengan Pendekatan RME}

Hasil analisis statistik yang berkaitan dengan skor hasil belajar matematika siswa setelah menerapkan model quantum learning dengan pendekatan RME sebagai berikut:

Tabel 4. Deskripsi Skor Hasil Belajar Matematika Siswa Setelah Penerapkan Model Quantum Learning dengan Pendekatan RME

\begin{tabular}{cc}
\hline Statistik & Nilai Statistik \\
\hline Ukuran sampel & 29 \\
Skor Terendah & 75 \\
Skor Tertinggi & 100 \\
Rata-rata & 88,10 \\
Skor ideal & 100 \\
Varians & 47,167 \\
Standar deviasi & 6,868 \\
Median & 90 \\
Modus & 85 dan 90 \\
Jangkauan & 25 \\
\hline
\end{tabular}

Berdasarkan tabel 4, nilai dari 29 siswa yang diajar dengan menggunakan model quantum learning dengan pendekatan RME diperoleh nilai terendah 75 dan nilai tertinggi 100 dengan rentang nilai 25 . Nilai yang mewakili sekumpulan nilai hasil belajar siswa yang menggunakan model quantum learning dengan pendekatan RME adalah 88,10 dengan standar deviasi adalah 6,868 artinya penyebaran datanya dominan berada pada 81,232 sampai 94,968 yang berkisaran antara 81 sampai 95 dari skor ideal 100. variansi 47,167 yang artinya tingkat kemampuan siswa cukup bervariasi (Nurhusain, 2016:19). Median 90 yang berarti $50 \%$ dari jumlah siswa memperoleh nilai diatas 90 dan 50\% siswa yang memperoleh nilai dibawah 90 . Modus 85 dan 90 yang berarti nilai terbanyak yang diperoleh siswa adalah 85 dan 90.

Tabel 5. Distribusi frekuensi dan Persentase Tes Hasil Belajar Siswa setelah Penerapan Model Quantum Learning dengan Pendekatan RME.

\begin{tabular}{ccccc}
\hline No. & Interval & Frekuensi & Persentase (\%) & Kategori \\
\hline 1 & $91-100$ & 8 & 27,6 & Baik Sekali \\
2 & $83-91$ & 14 & 48,3 & Baik \\
3 & $75-83$ & 7 & 24,1 & Cukup \\
4 & $<75$ & 0 & 0 & Kurang \\
\hline & Jumlah & $\mathbf{2 9}$ & $\mathbf{1 0 0}$ & \\
\hline
\end{tabular}

Berdasarkan tabel 5 dapat diketahui bahwa dari 29 orang siswa kelas VII 1 SMPN 1 Maros, pada umumnya mewakili tingkat hasil belajar matematika dalam kategori Baik setelah penerapan model quantum learning dengan pendekatan RME skor rata-rata 88,10 dari skor ideal 100. Sehingga dapat disimpulkan bahwa rata-rata hasil belajar matematika siswa setelah penerapan model quantum learning dengan pendekatan RME berada pada kategori Baik.

\section{c. Deskripsi Perbandingan Rata-rata Hasil Belajar Siswa sebelum dan setelah Penerapan Model Quantum Learning dengan Pendekatan RME.}

Penerapan model quantum learning dengan pendekatan RME diterapkan agar dapat meningkatkan hasil belajar siswa dan mengatasi masalah-masalah yang dihadapi siswa selama proses belajar matematika. Untuk mengetahui peningkatan hasil belajar 
matematika sebelum dan setelah penerapan model quantum learning dengan pendekatan RME dapat dilihat pada tabel 6.

Tabel 6. Deskripsi Perbandingan Rata-rata Hasil Belajar Siswa sebelum dan setelah Penerapan Model Quantum Learning dengan Pendekatan RME

\begin{tabular}{ccccccc}
\hline \multirow{2}{*}{ NO } & \multirow{2}{*}{ Skor } & \multirow{2}{*}{ Kategori } & \multicolumn{2}{c}{ Frekuensi } & \multicolumn{2}{c}{ Persentase(\%) } \\
\cline { 3 - 6 } & & & Pretest & Posttest & Pretest & Posttest \\
\hline 1 & $91-100$ & Baik Sekali & 0 & 8 & 0 & 27,6 \\
2 & $83-91$ & Baik & 0 & 14 & 0 & 48,3 \\
3 & $75-83$ & Cukup & 0 & 7 & 0 & 24,1 \\
4 & $<75$ & Kurang & 29 & 0 & 100 & 0 \\
\hline \multicolumn{2}{r}{ Jumlah } & & $\mathbf{2 9}$ & $\mathbf{2 9}$ & $\mathbf{1 0 0}$ & $\mathbf{1 0 0}$ \\
\hline
\end{tabular}

Berdasarkan tabel, sebelum penerapan model quantum learning dengan pendekatan RME, hasil belajar matematika siswa 100\% berada pada kategori kurang dan setelah penerapan model quantum learning dengan pendekatan RME, hasil belajar siswa berada pada kategori baik $48,3 \%$, sehingga rentang dari kategori yang diperoleh mengalami peningkatan. Selain itu, sebelum penerapan model quantum learning sebanyak 29 siswa tidak mencapai KKM yang ditetapkan disekolah yaitu 75. Namun setelah penerapan model quantum learning dengan pendekatan RME semua siswa telah mencapai KKM yang ditetapkan.

1) Uji Normalitas

Uji persyaratan analisis dalam penelitian ini adalah uji normalitas. Variabel pretest dan posttest dalam penelitian ini diuji sebaran normal datanya dengan menggunakan statistik chi square. Dari hasil analisis untuk menguji normalitas data dengan menggunakan chi square terhadap kedua variabel penelitian tersebut maka diperoleh: (1) hasil uji data sebelum penerapan model quantum learning dengan pendekatan RME yaitu $\chi^{2}$ hitung $=7,931$ pada taraf signifikan $\propto=0,05$ dan $\mathrm{dk}=8$, diperoleh $\chi^{2}$ tabel $=15,5$. (2) hasil uji data setelah menerapkan model quantum learning dengan pendekatan RME yaitu $\chi^{2}$ hitung $=5,966$ pada taraf signifikan $\propto=0,05$ dan $\mathrm{dk}=5$, diperoleh $\chi^{2}$ tabel $=11,1$. Berdasarkan hasil analisis

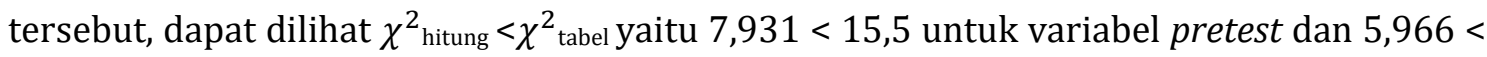
11,1 untuk variabel posttest, sehingga dapat disimpulkan bahwa data kedua variabel tersebut berdistribusi normal. Berikut disajikan ringkasan hasil analisis statistik uji normalitas untuk masing-masing variabel.

Tabel 7. Hasil Analisis Statistik Uji Normalitas

\begin{tabular}{cccccc}
\hline Variabel & Nilai $\chi^{2}$ hitung & Nilai $\chi^{2}$ tabel & Alfa $(\propto)$ & dk= k-1 & Keputusan \\
\hline Pretest & 7,931 & 15,1 & 0,05 & 8 & Normal \\
Posttest & 5,966 & 11,1 & 0,05 & 5 & Normal \\
\hline
\end{tabular}

Dengan demikian, data hasil belajar sebelum (pretest) dan setelah (posttest) penerapan model quantum learning dengan pendekatan RME tersebut berdistribusi normal.

2) Uji Hipotesis

1. $\mathrm{H}_{0}: \mu_{2} \leq 75$

$\mathrm{H}_{1}: \mu_{2}>75$

Untuk menguji hipotesis rata-rata skor hasil belajar matematika siswa setelah menerapkan model quantum learning dengan pendekatan RME melebihi KKM sebesar 75, 
peneliti menggunakan uji-t perbandingan rata-rata. Dari hasil perhitungan diperoleh $t_{\text {hitung }}$ $=10,274$ pada taraf signifikan $\propto=0,05$ dengan derajat kebebasan $(\mathrm{dk})=28$ diperoleh $\mathrm{t}_{\text {tabel }}$ $=1,701$ dengan kriteria pengujian menurut Lestari (2015:257) adalah jika $t_{\text {hitung }} \leq t_{\text {tabel }}$ pada taraf nyata dengan $t_{\text {tabel }}$ diperoleh dari distribusi t pada taraf $\propto=0,05$ maka $\mathrm{H}_{\mathrm{o}}$ diterima dan dalam keadaan hal lain $H_{o}$ ditolak. Karena diperoleh $t_{\text {hitung }}=10,274$ dan $t_{\text {tabel }}=1,701$ maka diketahui $t_{\text {hitung }}>t_{\text {tabel }}$ sehingga hipotesis yang menyatakan bahwa rata-rata skor hasil belajar matematika siswa kelas VII VIMN $_{1}$ Maros setelah penerapan model quantum learning dengan pendekatan RME lebih tinggi dari kriteria ketuntasan minimal yaitu 75, dapat diterima dengan tingkat kepercayaan 95\%.

2. $\mathrm{H}_{0}:$ gain $\leq 0,30$

$\mathrm{H}_{1}:$ gain $>0,30$

Untuk menguji hipotesis rata-rata skor hasil belajar matematika siswa setelah menerapkan model quantum learning dengan pendekatan RME melebihi nilai N-gain, yakni 0.30 , peneliti menggunakan uji-t perbandingan rata-rata. Dari hasil perhitungan diperoleh $\mathrm{t}_{\text {hitung }}=68,84$ pada taraf signifikan $\propto=0,30$ dengan derajat kebebasan $(\mathrm{dk})=28$ diperoleh $t_{\text {tabel }}=1,701$ dengan kriteria pengujian menurut (Lestari, 2015:257) adalah jika $t_{\text {hitung }} \leq t_{\text {tabel }}$ pada taraf nyata dengan $t_{\text {tabel }}$ diperoleh dari distribusi t pada taraf $\propto=0,30$ maka $\mathrm{H}_{\mathrm{o}}$ diterima dan dalam keadaan hal lain $\mathrm{H}_{\mathrm{o}}$ ditolak. Karena diperoleh $\mathrm{t}_{\text {hitung }}=68,84$ dan $\mathrm{t}_{\text {tabel }}=1,701$ maka diketahui $t_{\text {hitung }}>t_{\text {tabel }}$ sehingga hipotesis yang menyatakan bahwa rata-rata skor hasil belajar matematika siswa kelas VII.1 SMPN 1 Maros setelah penerapan model quantum learning dengan pendekatan RME lebih tinggi dari kriteria ketuntasan minimal yaitu 75, dapat diterima dengan tingkat kepercayaan 95\%.

Penelitian ini dilaksanakan di SMPN 1 Maros dan yang menjadi sampel penelitian adalah siswa kelas $\mathrm{VII}_{1}$ yang berjumlah 29 siswa. Penelitian dimulai 25 juli sampai 9 agustus 2018 yang terdiri dari 6 pertemuan. Pertemuan awal peneliti memberikan tes (pretest) berupa soal uraian berjumlah 5 butir soal pada materi bilangan bulat. Pada pertemuan kedua, ketiga dan keempat peneliti menerapkan model quantum learning dengan pendekatan RME, sedangkan pada pertemuan kelima peneliti memberikan tes (posttest). Penerapan model quantum learning dengan pendekatan RME telah memberikan hasil positif dengan terjadinya peningkatan hasil belajar matematika selama penelitian berlangsung siswa kelas VII $_{1}$ lebih termotivasi dan tahu arti dari pembelajaran matematika dengan pemberian contoh materi terkait dengan kehidupan sehari-hari. Selain itu, guru memupuk sikap juara terhadap masing-masing siswa agar berani menjawab pertanyaan yang diberikan.

Dalam hal ini rata-rata hasil belajar siswa kelas VII ${ }_{1}$ SMPN 1 Maros yang diajar menggunakan model quantum learning dengan pendekatan RME lebih tinggi dari KKM yaitu 75. Berdasarkan pengkategorian hasil belajar siswa menurut direktorat pembinaan sekolah menengah atas, 2017) dan kriteria ketuntasan minimal (KKM) SMPN 1 Maros yaitu sebesar 75 untuk mata pelajaran matematika menunjukkan bahwa rata-rata hasil belajar siswa sebelum menerapkan model quantum learning dengan pendekatan RME dikategorikan kurang yaitu 25,69 dan tidak mencapai KKM, sedangkan nilai rata-rata hasil belajar siswa setelah menerapkan model quantum learning dengan pendekatan RME dikategorikan baik yaitu 88,10. Hal ini menunjukkan bahwa rata-rata hasil belajar siswa setelah penerapan model quantum learning dengan pendekatan RME lebih tinggi dari KKM SMPN 1 Maros. 
Hasil pengamatan aktivitas siswa diperoleh bahwa setiap indikator aktivitas siswa menunjukkan peningkatan dari pertemuan pertama hingga pertemuan ketiga dan dengan penerapan model quantum learning dengan pendekatan RME menunjukkan rata-rata persentase aktivitas siswa yaitu $83,996 \%$ dan 16,004\% aktivitas siswa tidak tercapai dikarenakan masih adanya siswa yang kurang aktif di kelas tetapi hasil analisis aktivitas siswa menunjukkan bahwa partisipasi dan keaktifan siswa selama proses pembelajaran berlangsung secara umum berada pada kategori baik.

Dari hasil keterlaksanaan pembelajaran dengan menerapkan model quantum learning dengan pendekatan RME yang menilai semua aktivitas guru pada saat pembelajaran berlangsung menunjukkan rata-rata persentase $87,17 \%$ dan $12,83 \%$ aktivitas guru tidak tercapai dikarenakan pada pertemuan pertama guru belum melatih memori siswa dengan berdiskusi dan membandingkan jawaban dikarenakan masih dalam pemberian materi, pada pertemuan kedua guru tidak lagi memperkenalkan diri dan pada pertemuan terakhir guru tidak lagi memperkenalkan diri, tidak memberikan contoh kontekstual dan tidak mengarahkan siswa untuk membebaskan gaya belajar karena siswa sudah terbiasa. Hasil analisis keterlaksanaan pembelajaran menunjukkan bahwa keterlaksanaan pembelajaran selama proses pembelajaran berlangsung berada pada kategori sangat baik.

Dari hasil kegiatan yang dilakukan untuk menganalisis respons siswa dengan menghitung banyaknya siswa yang memberi respons dari angket yang diberikan kepada 29 siswa dengan jumlah 8 pernyataan yang bersifat positif. Setelah mengikuti pelajaran dengan menerapkan model quantum learning dengan pendekatan RME diperoleh rata-rata sebesar 89,65\% dan 10,35\% respons siswa kurang menyukai penerapan model quantum learning dengan pendekatan RME. Hal ini menunjukkan bahwa respons siswa terhadap proses pembelajaran berada pada kategori positif.

Dengan melihat hasil belajar siswa, aktivitas siswa, keterlaksanaan pembelajaran dan respons siswa, maka peneliti berkesimpulan bahwa dengan perpaduan penerapan model quantum learning dengan pendekatan RME efektif terhadap hasil belajar siswa kelas VII ${ }_{1}$ SMPN 1 Maros. Pembelajaran menjadi menyenangkan, sebab proses belajar diiringi dengan musik yang dapat meningkatkan kinerja otak sehingga diasumsikan bahwa belajar dengan diiringi musik akan mewujudkan suasana yang lebih menenangkan, serta pembelajaran dikaitkan dengan kehidupan nyata siswa, sehingga materi yang disampaikan lebih mudah dipahami oleh siswa.

Berdasarkan penelitian tersebut, diperkuat oleh pendapat Supardi (2015), bahwa pembelajaran dikatakan efektif jika didukung dengan unsur-unsur sumber daya manusia, fasilitas, perlengkapan, dan prosedur sehingga mengubah perilaku siswa ke arah yang positif dan lebih baik sesuai dengan potensi dan perbedaan yang dimiliki siswa untuk mencapai tujuan pembelajaran yang telah ditetapkan. Selain itu, penelitian Rismaratri \& Nuryadi (2017) menunjukkan bahwa pembelajaran quantum learning dengan pendekatan RME lebih berpengaruh baik terhadap kemampuan berfikir kreatif maupun motivasi belajar matematika siswa. Demikian juga penelitian yang dilakukan oleh Arifuddin (2016) menjunjukkan bahwa pembelajaran matematika model quantum teaching dengan pendekatan realistik dapat meningkatkan kemampuan pemahaman konsep peserta didik. 


\section{SIMPULAN}

Berdasarkan hasil analisis data dan pembahasan maka dapat disimpulkan bahwa penerapan model quantum learning dengan pendekatan RME efektif digunakan dalam meningkatkan hasil belajar matematika siswa kelas VII 1 SMPN 1 Maros adalah sebagai berikut: (1) Hasil uji hipotesis rata-rata skor hasil belajar matematika siswa setelah diterapkan model quantum learning dengan pendekatan RME diperoleh rata-rata hasil belajar matematika siswa setelah penerapan model quantum learning dengan pendekatan RME lebih tinggi atau sama dengan KKM SMPN 1 Maros yaitu 75; (2) Hasil belajar matematika siswa kelas VII 1 SMPN 1 Maros sebelum penerapan model quantum learning dengan pendekatan RME berada pada kategori kurang, yaitu dengan nilai rata-rata 25,69 sedangkan setelah penerapan model quantum learning dengan pendekatan RME berada pada kategori baik dengan nilai rata-rata 88,10 beserta hasil nilai gain adalah 0,83 diinterpretasikan pada kategori tinggi; (3) Aktivitas belajar siswa dengan menggunakan model quantum learning dengan pendekatan RME menunjukkan rata-rata persentase aktivitas siswa yaitu 83,996\% pada kategori baik; (4) Keterlaksanaan pembelajaran pada saat penerapan model quantum learning dengan pendekatan RME menunjukkan rata-rata persentase $87,17 \%$ berada pada kategori sangat baik; (5) Respons siswa setelah penerapan model quantum learning dengan pendekatan RME diperoleh rata-rata 89,65\% berada pada kategori positif.

\section{DAFTAR PUSTAKA}

Afriyanti, I., Wardono, \& Kartono. (2018). Pengembangan literasi matematika mengacu PISA melalui pembelajaran abad ke-21 berbasis teknologi. PRISMA (Prosiding Seminar Nasional Matematika), 1, 608-617. Retrieved from https://journal.unnes.ac.id/sju/index.php/prisma/article/view/20202.

Arifuddin, A. (2016). Pembelajaran matematika model quantum teaching dengan pendekatan realistik untuk meningkatkan kemampuan pemahaman konsep peserta didik. Al Ibtida Jurnal Pendidikan Guru MI, 3(2):186. Doi: 10.24235/al.ibtida.snj.v3i2.900.

Fathurrohman, M. (2015). Model-model pembelajaran inovatif alternatif desain pembelajaran yang menyenangkan. Yogyakarta: Ar-Ruzz Media.

Gunawan, M. . (2013). Statistik penelitian pendidikan. Yogyakarta: Parama Publishing.

Hayati, R., \& Husnidar. (2018). Penerapan metode quantum learning dalam pembelajaran matematika. Jurnal Sains Ekonomi dan Edukasi (JSEE), 6(2), 17-20. Retrieved from https://www.journal.ikipsiliwangi.ac.id/index.php/parole/article/view/3480.

Huda, M. (2015). Model-model pengajaran dan pembelajaran. Yogyakarta: Pustaka Pelajar.

Inganah, S., Cholily, Y. M., Taufik, M., \& Ummah, S. K. (2018). Peningkatan koneksi matematis melalui pembelajaran berbasis masalah di MAN I Malang. JINoP (Jurnal Inovasi Pembelajaran), 4(2), 151-159. Doi: 10.22219/jinop.v4i2.5003.

Jakni. (2016). Metodologi penelitian eksperimen bidang pendidikan. bandung: Alfabeta.

Jeranah. (2017). Efektivitas penerapan strategi Think Talk Write (TTW) dalam pembelajaran matematika ditinjau dari gaya belajar siswa. Makassar: Simposium Nasional MIPA Universitas Negeri Makassar.

Khotimah, S. H., \& As'ad, M. (2020). Pendekatan pendidikan matematika realistik terhadap hasil belajar matematika siswa sekolah dasar. Jurnal Ilmiah Pendidikan Dan Pengajaran, 4(3), 491-498. Doi: 10.23887/jipp.v4i3.28568. 
Laras, S. A., \& Rifai, A. (2019). Pengaruh minat dan motivasi belajar terhadap hasil belajar peserta didik di BBPLK Semarang. Jurnal Eksistensi Pendidikan Luar Sekolah (EPlus), 53(9), 121-130. Doi: 10.30870/e-plus.v4i2.7307.

Prasetyo, H. (2020). Kemampuan matematika siswa indonesia berdasarkan TIMSS. Jurnal Pedagogik, 3(2), 111-117. Doi: 10.35974/jpd.v3i2.2367.

Riati, T., \& Farida, N. (2017). Pengaruh model pembelajaran quantum learning terhadap kemampuan pemecahan masalah matematika siswa kelas VIII SMP PGRI 02 Ngajum. Pi: Mathematics Education Journal, 1(1), 15-21. Doi: 10.21067/pmej.v1i1.1999.

Rismaratri \& Nuryadi (2017). Pengaruh model pembelajaran quantum dengan pendekatan Realistic Mathematics Education (RME) Terhadap kemampuan berfikir kreatif dan motivasi belajar matematika. Jurnal Edukasi Matematika dan Sains, 5(2):70-76. Doi: $10.25273 /$ jems.v5i2.2012.

Sartika, N. S., \& S, S. R. Y. (2019). Penerapan model pembelajaran probing- prompting untuk meningkatkan kemampuan koneksi matematis. GAUSS: Jurnal Pendidikan Matematika, 01(02), 149-159. Doi: 10.30656/gauss.v1i2.103.

Silfitrah, S., \& Mailili, W. H. (2020). Pengaruh minat belajar dan motivasi belajar terhadap hasil belajar matematika siswa kelas VII SMP Negeri 4 Sigi. Guru Tua: Jurnal Pendidikan dan Pembelajaran, 3(1), 53-60. Doi: 10.31970/gurutua.v3i1.39.

Sudarman, S. W., \& Vahlia, I. (2016). Efektifitas penggunaan metode pembelajaran quantum learning terhadap kemampuan pemahaman konsep matematis mahasiswa. AlJabar: Jurnal Pendidikan Matematika, 7(2), 275-282. Doi: 10.24042/ajpm.v7i2.42.

Sudjana, N., \& Ibrahim. (2010). Penelitian dan penilaian pendidikan. Bandung: Penerbit Sinar Baru Algensindo Bandung.

Supardi. (2015). Sekolah efektif konsep dasar dan praktiknya. Depok: PT. Raja Grafindo Persada.

Swandewi, N. L. P., Gita, I. N., \& Suarsana, I. M. (2019). Pengaruh model quantum learning berbasis masalah kontekstual terhadap kemampuan berpikir kreatif siswa SMA. Jurnal Elemen, 5(1), 31. Doi: 10.29408/jel.v5i1.932.

Tiro, M. . (2015). Dasar-dasar statistik. Makassar: Andira Publisher. 